Pak. J. Agri., Agril. Engg., Vet. Sci., 2020, 36 (1): 55-60

ISSN: 1023-1072 (Print), ISSN: 2663-7863 (Online)

https://doi.org/10.47432/pjaaevs.2020.36.1.8

\title{
EVALUATION OF ANTI-PROTOZOAL ACTIVITY OF PEGANUM HARMALA (HARMAL) AGAINST BABESIOSIS IN CATTLE
}

\author{
M. I. Saleem ${ }^{1}$, S. A. Mahfooz ${ }^{1}$, M. M. Ashraf ${ }^{*}$, M. M. Jafar ${ }^{1}$ and A. Ashar ${ }^{3}$ \\ ${ }^{1}$ Department of Clinical Medicine and Surgery, University of Agriculture, Faisalabad, Pakistan \\ ${ }^{2}$ Department of Eastern Medicine, Government College University, Faisalabad, Pakistan \\ ${ }^{3}$ Department of Chemistry, Government College Women University, Faisalabad
}

\begin{abstract}
Babesia gradually attains resistance against the allopathic medicines due to their frequent use. To overcome the resistance, herbal therapy is getting more attention. The current study was planned to monitor the efficacy of Peganum harmala against babesiosis in cattle. The blood was collected from ear vein of cattle having high infestation of ticks. A thin blood smear was prepared and stained. Through survey 74 animals were found positive for tick-borne pathogens with an overall prevalence of $19.27 \%$. Babesia sp. was the most prevalent $(9.38 \%$; $36 / 384)$ haemoparasite, followed in order by Theileria sp. (5.20\%, 20/384) and Anaplasma sp. (4.69\%, 18/384). All blood samples were subjected to PCR and it was found that 40/384 (10.41\%) blood samples were harbouring Babesia bovis and Babesia bigemina. From positive animals for Babesia 30 cattles were randomly selected and divided into 3 groups of 10 animals each viz $\mathrm{A}, \mathrm{B}$ and $\mathrm{C}$, all groups were tested with the water extract of $P$. harmala @ $7.5 \mathrm{mg} \mathrm{kg}^{-1}, 10 \mathrm{mg} \mathrm{kg}^{-1}$ and $12.5 \mathrm{mg} \mathrm{kg}^{-1}$ body weight by intramuscular route, at interval of 12, 24 and $36 \mathrm{~h}$. Ten healthy animals were selected as control in group D. Three animals with moderate infection, 8-9 animals of group A, B and C were recovered, during $48 \mathrm{~h}$ after treatment. Two animals each from $A, B$ and one from group $C$ were not cured and died. Five animals from group $A$ were not cured till $36 \mathrm{~h}$ of the treatment. Group D of healthy untreated animals were well as they were. Results showed that there was a significant increase in WBCs, including increase in leukocytes and neutrophils in animals infected, whereas number of RBCs and HB decreases. This study concluded that infected cattle treated with water extract of $P$. harmala $12.5 \mathrm{mg} \mathrm{kg}^{-1}$, recovered early $(P<0.01)$ compared to that of 7.5 and $10 \mathrm{mg} \mathrm{kg}^{-1}$.
\end{abstract}

Keywords: herbal, infection, parasite, resistance, tick-borne

\section{INTRODUCTION}

Livestock sector plays a great role in development of the Pakistan's economy and there is still much more space in this sector to be focused. Keeping in mind, the end goal is to take care of an expanding demand of milk and milk products and it is auspicious to survey the current status of tick-borne diseases (TBDs) in Pakistan along with the learning of TBDs and their control. In livestock, babesiosis is caused by protozoan parasites (i.e. Babesia bovis and Babesia bigemina). The poor management of farms and lack of an acceptable framework to control or eradicate certain ticks may cause certain complications and later on may cause difficulty in control measures (Farkas et al., 2013). Tick-borne parasitic diseases are present all over the world. Tick-borne diseases (TBDs)

*Corresponding author:mudassar_pharmacist@yahoo.com and ticks influence the efficiency of bovines in tropical and subtropical ranges, prompting critical unfavourable effect on the jobs of asset poor cultivating groups. Tick-borne diseases cause a great loss in livestock production and have incredible financial effect in terms of high creation misfortunes and in addition mortality and increased consumption in treatment. Universally, four fundamental TBDs, to be specific babesiosis, cowdriosis (heartwater), anaplasmosis and theileriosis, influence bovines and are of major financial significance in bovines in Pakistan (Jabbar et al., 2015). Babesia species are protozoan parasites on cold-blooded vertebrates transferred by ixodidae ticks and are viewed as over whelming parasites (Duh et al., 2005). After trypanosomes Babesia is uppermost blood parasite found in mammals (Yabsley and Shock, 2012). It causes direct economic damages, such as mortality and 
lowered meat and milk production (Gharbi et al., 2011; Shahnawaz et al., 2011). For the treatment of babesiosis different therapeutic approaches are adopted. Diminazene aceturate and imidocarb dipropionate are commonly used anti Babesia drugs now a day. Supportive treatment and blood transfusions and the use of anti-inflammatory drugs, corticosteroids, and fluid therapy, are also advisable. Imidocarb is the most frequently used drug in Pakistan for the dealing with babesiosis (Niazi et al., 2008). It has also very serious effect on body like anaphylactic shock and resistance has been developed against these drugs due to its excessive use (Afifi et al., 2014).

To overcome the drug resistance, herbal therapy can be followed in such circumstances, there is intense need for the identification of such compounds that may skip these adverse effects. The pharmacological active ingredients of Peganum harmala are several alkaloids including $\beta$-carbolines such as harmaline, quinazoline, harman and harmatol and harmine derivative such as vasicinone as well as vasicine (Aarons et al., 1977). Peganum harmala (generally known as harmal) from family Zygophylaceae is a multiple used medicinal plant. Its main beta carboline alkaloids extracts are harmaline, harmine, harmalol and harmol (Herraiz et al., 2010). It is a bushy, and wildgrowing flowering plant with short roots (Shamsa et al., 2007; Goel et al., 2009) and is known as Harmal in North Africa and "Espand" in Iran and Syrian Rue or Turkish Rue or African Rue in United States (Mahmoudian et al., 2002).

Uptill date, no testimony is accessible on antiprotozoal effect of Peganum hermala at various dilutions for the treatment of babesiosis in cattle. Keeping in view the significant losses by babesiosis, the present project was planned to check the potential of Peganum hermala for the management of babesiosis in cattle in Faisalabad Punjab, Pakistan. The present study was planned to: determine haematological changes due to bovine babesiosis; access the therapeutic effect of extract of Peganum harmala against babesiosis in cattle.

\section{MATERIALS AND METHODS Study area}

The study area of this project was district Faisalabad. Faisalabad stands in the rolling flat plains of the northeast Punjab, between longitude $73^{\circ} 74$ east, latitude $30^{\circ} 31.5$ North, with an elevation of 184 meters (604 feet) above the sea level.

\section{Target population}

A total of 30 cattles (Bos indicus and Bostaurus) with positive babesia population were selected to evaluate the anti babesial activity of Peganum harmala.

\section{Clinical examination of babesiosis}

The blood samples were collected from the animals suspected for babesiosis on the basis of following clinical signs; ataxia, temperature, anorexia and in coordination, urine change in colour as brown or dark red-coloured urine (haemoglobinuria), marks of general circulatory shock, respiratory symptoms (tachypnoea, dyspnoea, pneumonia etc.), nervous signs, presence of ticks on the body of animals, in late course of disease haemoglobinuria and anaemia may appear, maximum parasitaemia (percentage of infected erythrocytes) in circulating blood less than $1 \%$ often occurs in acute cases (Bock et al., 2004).

\section{Sampling and investigations}

Blood sample were collected from marginal ear vein of cattle before treatment, on the basis of clinical signs. Blood sample of positive cattle were collected after treatment. Area of blood collection was disinfected with methyl alcohol. Ear vein was punctured with the help of 22 gauge needle, and samples were collected in sterilized disposable syringe of $5 \mathrm{~mL}$ capacity containing EDTA. The blood samples were stored at $4^{\circ} \mathrm{C}$ until future analysis (Benjamin, 1986).

\section{Slides preparation}

Thin blood smear was prepared from collected blood on clean and dry glass slides. These smears were air-dried, fixed in methyl alcohol for 10 minutes, stained with working dilution of Giemsa stain (1:10) with phosphate buffer solution and fixed for 30 minutes. To remove extra stain smear was washed with tap water, air-dried and examined under the oil immersion lens of a light microscope (Zafar et al., 2006). Parasites were recognized by method defined by Soulsby (1982).

\section{Extraction method of Peganum harmala}

The seeds of $P$. harmala were collected and taxonomically identified by Dr. M. Mansoor, Botanist in Department of Botany, University of Agriculture, Faisalabad. Then extract of $P$. harmala was prepared from the seeds of plant according to the method described by Manske and Holmes (1952). Crushed seeds of 
$P$. harmala were dissolved with three times, their weight of water containing $30 \mathrm{~g}$ of acetic acid per liter of water. The seeds swelled as they could absorb the liquid and form thick dough which was pressed after 3 days. The pressed seeds were again treated as above with twice, their mass of dilute acetic acid and after maceration and then liquid was again pressed and concentrated extract was sterilized in ultraviolet light for $12 \mathrm{~h}$ and dried below $70^{\circ} \mathrm{C}$ in an oven. Then, 10 grams of the dried extract was dissolved in $90 \mathrm{~mL}$ of distilled water and filtered with $0.2 \mu \mathrm{m}$ syringe filter and then injected to infected animal @ $7 \mathrm{mg} \mathrm{kg}^{-1}$ intramuscularly.

\section{Treatment trials}

A total of 30 babesia positive cattle selected for anti babesial activity were divided into three equal groups $\mathrm{A}, \mathrm{B}$ and $\mathrm{C}$ comprising 10 animals each. Groups A, B, and C were treated with different doses of the extract of $P$. harmala as $7.5 \mathrm{mg} \mathrm{kg}^{-1}, 10 \mathrm{mg} \mathrm{kg}^{-1}$ and $12.5 \mathrm{mg} \mathrm{kg}^{-1}$ body weight intramuscularly for 3 days. The parameters of infected animals of group A, B and $\mathrm{C}$ were compared with the normal parameters of healthy animals of group $D$ $(n=10)$.

\section{Haematological parameters}

A total of 160 blood samples from 30 babesia positive species and 10 samples of control group after $12 \mathrm{~h}$ interval of treatment were also taken. Different haematological parameter changes were studied like white blood cells (WBC's), haemoglobin (Hb), Packed Cell Volume (PCV) and Red blood cells (RBC's).

\section{Statistical analysis}

The results were analysed under two ways factorial of complete randomized design to find out any association of hypothesized risk factors with the occurrence of disease. The study was conducted on tick vectors because ticks are abundantly found in Pakistan due to humidity, sanitation and hygienic issues (Makala et al., 2003; George et al., 2004).

\section{RESULTS AND DISCUSSION}

The study was conducted to check the activity of Peganum harmla against blood protozoal disease. Different methods had been used so far to treat babesiosis in cattle which include therapeutic control and vaccination (Bock et al., 2004; Niazi et al., 2008). Current live vaccines against $B$. bovis and and $B$. pigemina are based on attenuation techniques (Florin-Christensen et al., 2014). It was first to use against babesiosis and it showed positive results due to its resemblance towards natural infection but this treatment proved to be lethal for those cattle which have poor immune system since the attenuated vaccine may re-mutate to produce severe results and even death can occur in aged animals.

On the other hand, some therapeutic approaches have been adopted in the treatment of babesiosis. Diminazenediaceturate (Kumar et al., 2016) and imidocarb dipropionate (Akhtar et al., 2010) are commonly used anti babesial drugs now a day. These drugs have very serious effect on body like anaphylactic shock, toxicosis, diarrhoea and dyspnoea excessive salivation (Afifi et al., 2014). But some downsides of these drugs have been seen in modern research as compared to the $P$. harmla extract. These disadvantages may be noticeable in pregnant cattle in the form of severe miscarriages moreover many other side effects. All these reasons confirmed some new medicinal researches that are resulted in the form of $P$ harmla extract due to its well antiprotozoal repute in former ages (Mirzaei, 2007), thus this experiment was conducted to confirm the efficacy of $P$. harmla against babesiosis as this plant may show effective results according to Moloudizargari et al. (2013).

A survey was directed in Ethiopia to find out the prevalence of babesiosis in dairy animals. For this purpose, 384 animals were randomly screened. Results indicated that female animals have a higher incidence of babesiosis than that of the male animals which is $17.5 \%$ vs $16.3 \%$ (Hamsho et al., 2015) and these results correlate with the rate of incidence found in present study. The age restricted prevalence of protozoal infections divulged that adult cattle are more susceptible towards the hemoprotozoal diseases as compared to young ones. In current study, the higher rate of susceptibility of adult cattle to babesiosis is reinforced by the findings of Anand et al. (2009). These observations were also correlated with the observations of Kamani et al. (2010) who mentioned the higher prevalence of adult than that of young cattle. As far as the sex is concerned, in this study female cattle was more likely to be affected relative to male cattle. Significantly the high prevalence ratio of babesiosis was observed for female cattle that were reported by Alim et al. (2012). The haematology was performed because this disease has intra-erythrocytic parameters of 
blood (Yadav et al., 2015). Thus, the haematological changes observed in this research are as follows:

Level of WBCs at different doses in infected animals

Figure 1 shows that with the dose of $7.5 \mathrm{mg} \mathrm{kg}^{-1}$, no effect was observed up to $24 \mathrm{~h}$ and WBCs number was elevated but after $36 \mathrm{~h}$ this level of WBCS start dropping. In animals treated with 10 $\mathrm{mg} \mathrm{kg}{ }^{-1}$ BW the drop in WBCs number was observed at $24 \mathrm{~h}$ which continued till $36 \mathrm{~h}$. In animals treated with $12.5 \mathrm{mg} \mathrm{kg}^{-1} \mathrm{BW}$, the number of WBCs did not show significant increase after first dose and dropped significantly up to $24 \mathrm{~h}$.

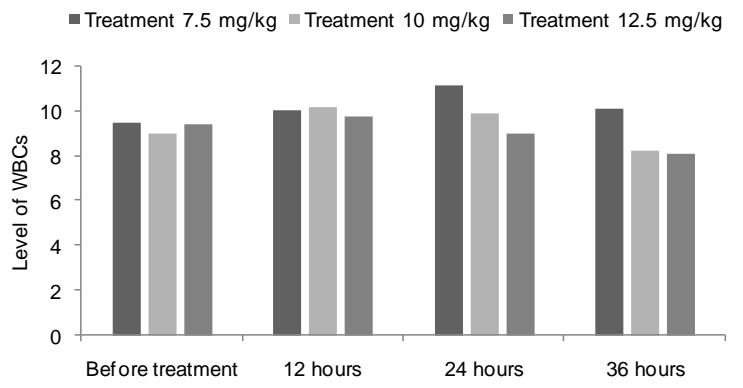

Figure 1. Level of WBCs in treated animals during the course of disease

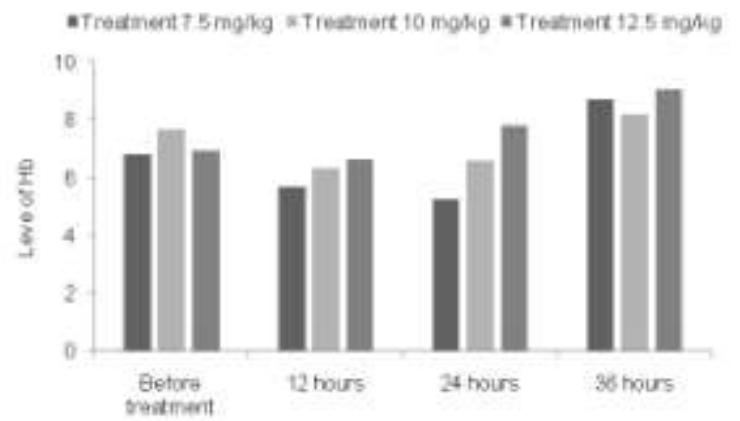

Figure 2. Level of PCV in treated animals during the course of disease.

\section{Level of PCV at different doses in infected animals}

Figure 2 shows that with the doses of $7.5 \mathrm{mg}$ $\mathrm{kg}^{-1}$, no effect was observed up to $24 \mathrm{~h}$ as PCV Value dropped down to $24 \mathrm{~h}$. After $36 \mathrm{~h}$, this level of PCV started increasing. In animals treated with $10 \mathrm{mg} \mathrm{kg}^{-1} \mathrm{BW}$, increase in PCV Value was observed at $24 \mathrm{~h}$ which continued till $36 \mathrm{~h}$. In animals treated with $12.5 \mathrm{mg} \mathrm{kg}^{-1} \mathrm{BW}$, PCV value did not show significant drop after first dose.

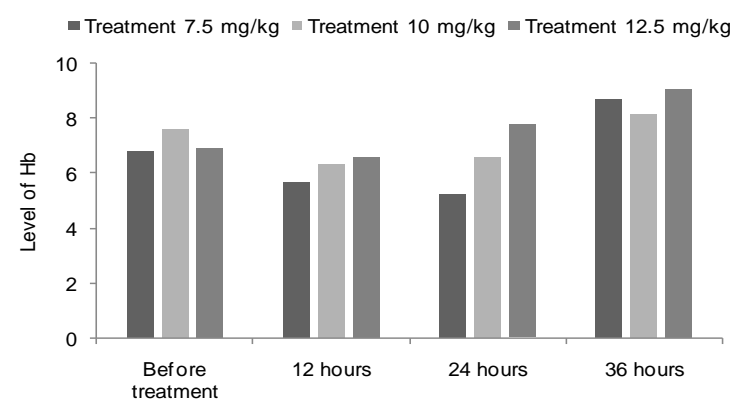

Figure 3. Level of HB in treated animals during the course of disease.

\section{Level of HB at different doses in infected animals}

Figure 3 shows that with the dose of $7.5 \mathrm{mg} \mathrm{kg}^{-1}$, no effect was observed upto $24 \mathrm{~h}$ and $\mathrm{Hb}$ level dropped continuously but after $36 \mathrm{~h}$ this level of $\mathrm{Hb}$ showed significant increase. In animals treated with $10 \mathrm{mg} \mathrm{kg}^{-1} \mathrm{BW}$, the drop in $\mathrm{Hb}$ value was observed at $12 \mathrm{~h}$ which reversed till $36 \mathrm{~h}$. In animals treated with $12.5 \mathrm{mg} \mathrm{kg}^{-1} \mathrm{BW}$, the number of WBCs did not show significant decrease after first dose.

\section{CONCLUSION}

Results of this study hence prove that aqueous extract of $P$. harmala was more effective at the rate of $12.5 \mathrm{mg} \mathrm{kg}^{-1}$ than that of 7.5 and $10 \mathrm{mg}$ $\mathrm{kg}^{-1}$ body weight against babesiosis in cattle.

\section{ACKNOWLEDGEMENT}

We are wholeheartedly thankful to the Faculty of Veterinary Sciences, University of Agriculture Faisalabad, for the technical support they gave us. They provided us with all the necessary equipment and apparatus, as and when we needed.

\section{AUTHOR'S CONTRIBUTION}

M. I. Saleem: Conducted research

S. A. Mahfooz: Helped in planning research

M. M. Ashraf: Data collection and interpretation

M. M. Jafar: Data analysis

A. Ashar: Data interpretation

\section{REFERENCES}

Aarons, D. H., G. V. Rossi and R. F. Orzechowski. 1977. Cardiovascular actions of three harmala alkaloids: Harmine, harmaline, and harmalol. Journal of Pharmaceutical Science, 66 (9): 1244-1248.

Afifi, N. A., I. M. Shihata, H. Y. El-Zorba and I. M. Ismail. 2014. Effect of Imidocarb dipropionate on the immune response to Foot and Mouth Disease vaccine in healthy 
and anaplasmosis-infected calves. Veterinary World, 7 (3): 162-167.

Akhtar, K. P., S. Haidar, M. K. R. Khan, M. Ahmad, N. Sarwar, M. A. Murtaza and M. Aslam. 2010. Evaluation of Gossypium species for resistance to Cotton Leaf Curl Burewala virus (CLCuBV). Annals of Applied Biology, 157 (1): 135-147.

Alim, M. A., S. Das, K. Roy, M. Masuduzzaman, S. Sikder, M. M. Hassan, A. Z. Siddiki and M. A. Hossain. 2012. Prevalence of hemoprotozoan diseases in cattle population of Chittagong division, Bangladesh. Pakistan Veterinary Journal, 32 (2): 221- 224.

Anand, V. C., L. Daboussi, T. C. Lorenz and G. S. Payne. 2009. Genome-wide Analysis of AP-3-dependent Protein Transport in Yeast. Molecular Biology of the Cell, 20 (5): 15921604.

Benjamin, M. M. 1986. Outline of Veterinary Clinical Pathology. Ames lowa USA. The lowa State University Press, 3: 29-30.

Bock, R., L. Jackson, A. D. Vos and W. Jorgensen. 2004. Babesiosis of cattle. Parasitology, 129 (1): 247-269.

Duh, D., M. Petrovec and A. T. Zupanc. 2005. Molecular characterization of human pathogen Babesia EU1 in Ixodesricinus ticks from Slovenia. Journal of Parasitology, 91 (2): 463-465.

Farkas, R., A. Estrada-pena, T. G. T. Jaenson, I. Pascucci and M. Madder. 2013. Basic biology and geographical distribution of tick species involved in the transmission of animal pathogens, including zoonoses. pp. 6-26 in Ticks and Tick-borne Diseases: Geographical Distribution and Control Strategies in the Euro-Asia Region. Wallingford $C A B$ International.

Florin-Christensen, M., C. E. Suarez, A. E. Rodriguez, D. A. Flores and L. Schnittger. 2014. Vaccines against bovine babesiosis: where we are now and possible roads ahead. Parasitology, 141 (12): 1563-1592.

George, J., Y. T. Phun, M. J. Bailey, D. C. Kong and K. Stewart. 2004. Development and validation of the medication regimen complexity index. Annals of Pharmacology, 38 (2): 369-376.

Gharbi, M., A. Touay, M. Khayeche, J. Laarif, M. Jedidi, L. Sassi and M. A. Darghouth. 2011. Ranking control options for tropical theileriosis in at-risk dairy cattle in Tunisia, using benefit cost analysis. Revue scientifique et technique (International Office of Epizootics), 30 (3): 763-778.
Goel, N., N. Singh and R. Saini. 2009. Efficient in vitro multiplication of Syrian Rue (Peganum harmala L.) using 6benzylaminopurine pre-conditioned seedling explants. Natural Science, 7 (7): 129-34.

Hamsho, A., G. Tesfamarym, G. Megersa and M. Megersa. 2015. A Cross-sectional study of Bovine Babesiosis in Teltele district, Borena Zone, Southern Ethiopia. Journal of Veterinary Science and Technology, 6 (230): 2-4.

Herraiz, T., D. González, C. A. Azpilicueta, V. J. Arán and H. B. Guillén. 2010. B-Carboline alkaloids in Peganum harmala and inhibition of human monoamine oxidase (MAO). Food and Chemistry Toxicology, 48 (3): 839-845.

Jabbar, A. T., Z. Abbas, H. A. Sandhu, M. F. Saddiqi, Qamar and R. B. Gasser. 2015. Tick-borne diseases of bovines in Pakistan: major scope for future research and improved control. Parasites and Vectors, 8 (1): 283.

Kamani, J., A. U. Mani and G. O. Egwu. 2010. Seroprevalence of Toxoplasma gondii infection in domestic sheep and goats in Borno State, Nigeria. Tropical Animal Health Product, 42 (4): 793-797.

Kumar, N. V., J. Yang, K. Pillai, S. Rawat, C. Solano, A. Kumar, M. Grøtli, T. L. Stemmler, B. P. Rosen and M. J. Tamás. 2016. Arsenic directly binds to and activates the yeast AP1-like transcription factor Yap8. Molecular and Cellular Biology, 36 (6): 913-922.

Mahmoudian, M., H. Jalilpour and P. Salehian. 2002. Toxicity of Peganum harmala: Review and a Case Report. Iranian Journal of Pharmacology and Therapeutics, 1 (1): 1-4.

Makala, L. H., P. Mangani, K. Fujisaki and H. Nagasawa. 2003. The current status of major tick borne diseases in Zambia. Veterinary Research, 34 (1): 27-45.

Manske, R. H. F. and H. L. Holmes. 1952. The Alkaloids: Chemistry and Pharmacology. Academic Press New York USA, 1: 513-551.

Mirzaei, M. 2007. Treatment of natural tropical theileriosis with the extract of the plant Peganum harmala. Korean Journal of Parasitology, 45 (4): 267-271.

Moloudizargari, M., P. Mikaili, S. Aghajanshakeri, M. H. Asghari and J. Shayegh. 2013. Pharmacological and therapeutic effects of Peganum harmala and its main alkaloids. Pharmacognosy Reviews, 7 (14): 199-212.

Niazi, N., M. S. Khan, M. Avais, J. A. Khan, K. Pervez and M. A. ljaz. 2008. A study 
on babesiosis in calves at livestock experimental station Qadirabad and adjacent areas, Sahiwal. Pakistan Journal of Agriculture Science, 45 (2): 209-211.

Shahnawaz, S., M. Ali, M. A. Aslam, R. Fatima, Z. I. Chaudhry, M. U. Hassan, M. Ali and I. Furhan. 2011. A study on the prevalence of a tick transmitted pathogen, Theileria annulata, and hematological profile in cattle from Southern Punjab. Parasitology Research, 109 (4): 1155-1160.

Shamsa, F., H. R. Monsef, R. Ghamooghi and M. R. R. Verdian. 2007. Spectrophotometric determination of total alkaloids in Peganum harmala L. using bromocresol green. Research Journal of Phytochemistry, 1 (2): 79-82.
Soulsby, E. J. L. 1982. Helminths, arthropods and protozoa of domesticated animals, $7^{\text {th }}$ Ed. The English Language Book Society and Bailliere Tindall, London, ISBN: 10: 0702008206.

Yabsley, M. J. and C. B. Shock. 2012. Natural history of Zoonotic Babesia: Role of wildlife reservoirs. International Journal of Parasitology, Parasite and Wildlife, 2: 18-31.

Yadav, A., A. Radhakrishnan, G. Bhanot and H. Sinha. 2015. Differential regulation of antagonistic pleiotropy in synthetic and natural populations suggests its role in adaptation. G3: Genes, Genomes, Genetics, 5 (5): 699-709.

Zafar, I., M. S. Sajid, A. Jabbar, Z. A. Rao and M. N. Khan. 2006. Techniques in Parasitology. Higher Education Commission Islamabad Pakistan, pp. 35-40.

(Received: June 06, 2018; Accepted: January 01, 2020) 